This item was submitted to Loughborough's Research Repository by the author.

Items in Figshare are protected by copyright, with all rights reserved, unless otherwise indicated.

\title{
Durkheim and sociological method: historical sociology, sports history and the role of comparison
}

PLEASE CITE THE PUBLISHED VERSION

http://dx.doi.org/10.1080/09523367.2015.1108968

\section{PUBLISHER}

(C) Taylor \& Francis

\section{VERSION}

AM (Accepted Manuscript)

\section{PUBLISHER STATEMENT}

This work is made available according to the conditions of the Creative Commons Attribution-NonCommercialNoDerivatives 4.0 International (CC BY-NC-ND 4.0) licence. Full details of this licence are available at: https://creativecommons.org/licenses/by-nc-nd/4.0/

\section{LICENCE}

CC BY-NC-ND 4.0

\section{REPOSITORY RECORD}

Malcolm, Dominic. 2019. "Durkheim and Sociological Method: Historical Sociology, Sports History and the Role of Comparison". figshare. https://hdl.handle.net/2134/19255. 
Durkheim and Sociological Method: Historical Sociology, Sports History and the Role of Comparison

Dominic Malcolm (Loughborough University)

This article provides sociological reflections on the use of research methods in the history of sport. In light of the convergence of social scientific approaches and social research methods in recent years, it draws upon Durkheim's reflections on the principles of sociology to explore the potential of the discipline to provide a distinctive methodological orientation to the study of sport. It subsequently uses this framework to assess the tendency in sports history to present interview data in non-anonymized form, and to advocate the value of particular kinds of comparative analysis for forwarding our understanding of the social world.

A formative moment in the development of sociology was the 1895 publication of Emile Durkheim's The Rules of Sociological Method. ${ }^{1}$ For Durkheim, the discipline’s viability depended upon the identification of a distinct object of study, requiring a distinct method of investigation. He embarked on a search for 'social facts' characterized by three criteria: externality (valid beyond individual humans); constraint (the consequence of living with other humans); and generality/independence (the behavioural similarities and differences between social groups and contexts). In so doing, Durkheim sought the study of observable, unconscious mental entities or 'collective representations' in order to deliver 'a conception of the world which as far as possible is not the view from anywhere within it'. ${ }^{2}$ By this definition, sociological method must enable us to conceive of the social world at a relatively high level of generality.

The formation of sociology occurred relative to the pre-existing natural sciences and disciplines such as psychology, philosophy and history. Durkheim dismissed psychology as 
too individualistically oriented. Conversely he argued that the analytic scope of philosophy had the potential to provide 'a complete systematisation of experiences', ${ }^{3}$ but considered that detailed empiricism was required to go beyond its essentially abstract and speculative character. His view of history however was particularly equivocal. Highly critical of much historical work - 'normally the historian perceives only the most superficial part of social life ${ }^{4}$ - he professed that 'I know of no sociology worthy of the name which does not possess a historical character'. ${ }^{5}$ Influenced by the approach (if not the thesis) of Marx, Durkheim identified the potential of sociology to counter the tendency in historical research to privilege accounts of individuals (motives and interpretations) and thus subsequently fail to reveal the broader structural dynamics of social change (for Marx, for example, class conflict).

While aspiring to philosophy's ambition and history's positivist rigour, Durkheim believed that comparison would provide sociology's unique methodology. Comparison could take three forms - intra-societal, inter-societal or cross-species - but the wider the scale of comparison the better: 'What we [sociologists] must look for is a means of comparing historical data, and establish series of phenomena which vary along parallel lines'. ${ }^{6}$ For example, Durkheim famously compared suicide rates in different societies in order to make more general claims about the structure of those particular societies. ${ }^{7}$ For Durkheim, 'The comparative method is the sole one suitable for sociology' ${ }^{8}$

A century later the context is very different. Sociology has become a fractured discipline with, for instance, many sociologists working in business schools, sports science and, increasingly, health departments. ${ }^{9}$ Some perceive sociologists of sport to be facing a crisis due to specialization and scientization which has led to their positioning at the 'bottom of the epistemological hierarchy'. ${ }^{10}$ Multidisciplinarity has been identified as a solution, and this movement has been aided by the widespread rejection of Durkheimian positivism, and its replacement with a stronger vein of interpretivism and qualitative methods. 
It is perhaps for this reason that there is little particularly distinctive about contemporary sociological research methods. There is, for example, a plethora of social research methods texts and a dearth of texts devoted specifically to sociological research methods. Thus to assess what sociological method can contribute to sports history, and notwithstanding a personal advocacy of historical or developmental sociology, it is useful to return to a conception of sociology's distinctive intellectual mission vis-à-vis Durkheim. In what follows I present one specific and one more generic consideration. First, I comment on the increasing use of interview data in historical analyses of sport. Second, I develop that point by highlighting the importance of comparison and of positioning explanations at a level of generality that allows us to explore the broader character of social systems.

The use of interviewing in historical studies is to be welcomed for it contributes to the rejection of the somewhat false dichotomy of past and present which has divided sociology and history. ${ }^{11}$ But if one compares the interview data that sociologists and historians present, a distinct difference is immediately apparent. Specifically, historians frequently directly attribute quotes to named individuals and have not adopted the conventions of anonymity and confidentiality. Why should this be?

There are ethical, practical but also broader conceptual implications of this practice. As outlined in the ethical guidelines of the British Sociological Association, the safeguarding of research subjects' privacy is fundamental. ${ }^{12}$ The rationale for this is that if we can protect their identity, interviewees are more likely to honestly and fully divulge information. It therefore also has a strongly practical element to it - i.e. it improves the reliability and validity of data. Most would argue that there can and should be exceptions to preserving anonymity, but those exceptions should be justified on a case-by-case basis and the practice should 'not ... discarded lightly'. ${ }^{13}$ Failing to offer interviewees the option of anonymity is problematic as it might restrict the kind and depth of information they are prepared to divulge. 
Underpinning differences in presenting interview data are divergent conceptual views. One reason for citing the names of interviewees seems to be the desire to give the individual's perspective a ring of authenticity - they were there, so they know. But providing names also seems to represent a continuation of the propensity in history to privilege accounts of individuals. In so doing, it needlessly focuses attention on relatively insignificant information, and concomitantly detracts from asking more expansive questions about social structure. We should not treat interview data as though it 'speaks for itself'. We 'cannot rely on naive readings of interview data ... we must not take at face value insiders' explicit rationales for action'. ${ }^{14}$ Rather (and I recognize that this runs counter to the recent popularity of auto-ethnography) the words of interviewees are of value because they are indicative of a broader body of (theory and) interview data. We need to subject interviewees' accounts to systematic and comparative analysis if we are to avoid reducing the social to the individual. ${ }^{15}$ Durkheim's The Rules of Sociological Method urged us to understand such agency perspectives in relation to their interdependence with broader structural dynamics of social change. While historians should consider the general applicability of social science interview data analysis techniques, the broader issue of orientation and scope is equally important.

The differences between sociological and historical uses of interview data are also reminiscent of Durkheim's emphasis on comparison. Of course, comparison is not the preserve of the sociologist - indeed 'sports historians are forever making comparisons, ${ }^{16}$ but just like their respective uses of interview data, we can see that historians and sociologists tend to use comparison in different ways. For while Booth argues that 'comparisons help historians understand the nature of sport, its different functions and meanings, the diversity of factors that shape sport and influence participation, and how individuals and groups make sense of sport and use it for their own ends, ${ }^{17}$ comparison for (Durkheimian) sociologists is a tool for making more wide-ranging claims about the structural characteristics of particular 
societies. In other words, my reading of sports history is that comparisons are commonly drawn to highlight the specificity of a particular phenomenon upon which an individual historian has gathered primary data, while sociologists are more likely to subject cognate studies to comparison in order to construct explanations which extend beyond the scope of any single study.

By way of illustration consider my earlier work on the development of cricket in American. ${ }^{18}$ This study relies, pace Durkheim, on both inter- and intra-societal comparison.

1) Inter-societal comparison enables the debunking of existing theses of the 'demise' of cricket in America. Firstly, comparison highlights anomalies in explanations based on notions of limited 'sports space' (i.e. baseball replaced cricket because there was insufficient 'sports space' for the two to co-exist). Comparison of studies which employ this concept shows variable 'amounts' of sports space which in turn suggests that these estimations are either somewhat arbitrary or teleological. Secondly, intersocietal comparison problematizes the supposed disjuncture between the properties of cricket and national character, for it is difficult to accept that the different 'national characters' of India, South Africa, Australia and England are equally conducive to the game’s uptake, while those of Scotland, Ireland and America are equally averse.

2) Intra-societal comparison shows first that rule changes did not necessarily make baseball more American in character (i.e. faster and shorter) or more distinct from cricket (e.g. abolition of catching 'on the fly'). Second, a comparison of historical studies of cricket in various American regions, shows the geographically heteronomous diffusion of cricket in America; that is to say, developed by different classes in different places, in the context of varying configurations of social class relations and thus with different outcomes. 
3) Inter-societal comparison of the different social class and economic relations in American and English cricket in the nineteenth century exposes the broader social structural dynamics behind cricket's demise. In particular, the context of commercialization, amateur-professional relations and debates over what constituted legitimate bowling techniques, indicate that the game being diffused 'from’ England was not of a unitary nature. Moreover, it helps explain why Harry Wright, a professional employed by the St George's Cricket Club in New York, should consider the formation of the first professional baseball team (the Cincinnati Red Stockings) more commercially viable than founding a professional cricket team.

I am not saying that historians do not, or cannot, undertake the kind of comparative approach advocated here. Similarly I am not saying that history does not or cannot ask the 'bigger', structural questions about collective representations and the dynamics of social development which Durkheim envisaged as sociology’s distinctive mission. Indeed, to turn that position on its head, sociology cannot address these types of question without an inherently historical orientation. But the implication of this example is to question whether the collection of primary data from archives is the only profitable mode of (historical) analysis.

Rather, I would argue that the production of more adequate knowledge about our social world requires cooperation across disciplines (and generations). As it is impossible for any individual to undertake all the primary data gathering required for the kind of 'complete systematization of experiences', cross-fertilization of studies is a necessity. Our goal should be the synthesis of understanding of higher and lower levels of generality and fundamental to this is the extensive use of comparison. 


\section{Biographical Note}

Dominic Malcolm is Reader in the Sociology of Sport in the School of Sport, Exercise and Health Sciences at Loughborough University.

Notes

${ }^{1}$ Emile Durkheim, The Rules of Sociological Method: And Selected Texts on Sociology and its Method, edited by Steven Lukes (Basingstoke: Macmillan, 1982).

2 Thomas Nagel, 'Subjective and Objective', in Mortal Questions (London: Cambridge University Press, 1979) cited in Lukes 'Introduction’, Ibid., p.12.

${ }^{3}$ Emile Durkheim, 'Sociology and the Social Sciences’ (1903), ibid., p.176.

${ }^{4}$ Emile Durkheim, 'Marxism and Sociology: The Materialist Conception of History' (1897), ibid., p.167.

${ }^{5}$ Emile Durkheim, 'Debate on Explanation in History and Sociology' (1908), ibid., p.211.

${ }^{6}$ Emile Durkheim, 'Debate’, p.218.

${ }^{7}$ Emile Durkheim, On Suicide (London: Penguin Books, 2006).

${ }^{8}$ Emile Durkheim, The Rules of Sociological Method (1895), ibid., p.147.

${ }^{9}$ Dominic Malcolm, 'Sport, Medicine and Health: A Research Agenda for Social Scientists', Asia-Pacific Journal of Sport and Social Science 3 no. 1 (2014), 51-63.

${ }^{10}$ David Andrews, ‘Kinesiology’s Inconvenient Truth and the Physical Cultural Studies Imperative, Quest 60 (2008), 45-62.

${ }^{11}$ Eric Dunning, Dominic Malcolm and Ivan Waddington (eds), Sport Histories: Figurational Studies in the Development of Modern Sport (London: Routledge, 2004)

${ }^{12}$ Statement of Ethical Practice for the British Sociological Association (2002), http://www.britsoc.co.uk/media/27107/StatementofEthicalPractice.pdf. Accessed 15 May 2015.

${ }^{13}$ Ibid.

${ }^{14}$ Sarah. Nettleton and Judith Green, 'Thinking about Changing Mobility Practices: How a Social Practice Approach can Help’, Sociology of health \& illness 36 no. 2 (2014), 248.

${ }^{15}$ Paul Atkinson, 'Illness Narratives Revisited: The Failure of Narrative Reductionism', Sociological Research Online 14 No. 5 (2009)

${ }^{16}$ Douglas Booth, The Field: Truth and Fiction in Sport History (London: Routledge, 2005), p.127. 
${ }^{17}$ Ibid., p.127.

${ }^{18}$ Dominic Malcolm, 'The Diffusion of Cricket to America: A Figurational Sociological Examination', Journal of Historical Sociology, 19 no. 2 (2006), 151-173. 